ENTREPRENEURSHIP AND SUSTAINABILITY ISSUES

ISSN 2345-0282 (online) http://jssidoi.org/jesi/ 2019 Volume 7 Number 1 (September)

http://doi.org/10.9770/jesi.2019.7.1(23)

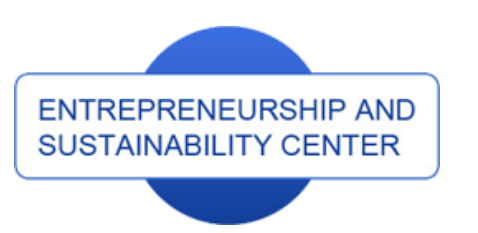

Publisher

http://jssidoi.org/esc/home enterprise

europe

network

Business Support on Your Doorstep
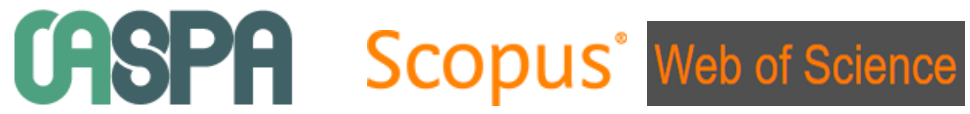

Clarivate
Analytics

\title{
DEVELOPING ENTERPRISE COMPETITIVE ADVANTAGE AS A COMPONENT OF ANTI-CRISIS MANAGEMENT
}

\author{
Tetiana Balanovska ${ }^{1}$, Oksana Havrysh ${ }^{2}$, Olga Gogulya ${ }^{3}$ \\ ${ }^{1,3}$ National University of Life and Environmental Sciences of Ukraine, Department of Management named after prof. \\ J.S. Zavadskyi, Heroyiv Oborony Street, 15, 03041 Kyiv, Ukraine \\ ${ }^{2}$ State University of Telecommunications, Department of Management, Solomenska Street, 7, 03680, Kyiv, Ukraine \\ E-mails:.1 balanovskaya@nubip.edu.ua,; ${ }^{2}$ oksanahavrysh_dut@ukr.net; ${ }^{3}$ ogogulya@ukr.net
}

Received 15 March 2019; accepted 14 July 2019; published 30 September 2019

\begin{abstract}
The article describes the concept of enterprise anti-crisis management, an important component of which is the formation and development of competitive advantages. Due to various factors, enterprise competitive advantages can be internal, which are, being subject to change, completely controlled by management of enterprises, and external - the ones that enterprises cannot quickly deal with. The study analyses the current state of activity of the information and telecommunications enterprises in Ukraine, which results in the determined reasons for a slowdown in development of small and medium-sized telecommunication enterprises (SMEs). The list of services of telecommunication enterprises, amongst which mobile communication services are of the highest demand, is provided. The problems of Ukraine's mobile communication market development are determined. It is emphasized that enterprises should constantly implement anticrisis management, which implies the development of telecommunication enterprise competitive advantages. Using the multi-factor correlation-regression analysis, a model of the dependence of net profit on the main types of costs is constructed. Applying the model will enable telecommunication enterprises to predict change in the net profit depending on changes in labour costs and costs of social events, material costs, depreciation and other operating costs, which will contribute to the development of their competitive advantages. The study offers the anti-crisis management mechanism providing timely determination of availability, as well as expediency of development of a competitive advantage, for a telecommunication enterprise.
\end{abstract}

Keywords: development; competitive advantages; anti-crisis management; enterprise; profit, costs

Reference to this paper should be made as follows: Balanovska, T.; Havrysh, O.; Gogulya, O. 2019. Developing enterprise competitive advantage as a component of anti-crisis management, Entrepreneurship and Sustainability Issues 7(1): 303-323. http://doi.org/10.9770/jesi.2019.7.1(23)

JEL Classifications: L1, M10, M19, M21, O14

\section{Introduction}

Under today's market conditions, enterprises, in any field of activity, operate under strong competition. Nowadays, there is a decline in the competitiveness of many Ukrainian enterprises with the deepening of existing crisis situations in their activities and emergence of new ones together with deterioration of living conditions and financial results. Dynamic environment external factors, including negative ones, also have a significant impact 


\section{ENTREPRENEURSHIP AND SUSTAINABILITY ISSUES}

ISSN 2345-0282 (online) http://jssidoi.org/jesi/

2019 Volume 7 Number 1 (September)

http://doi.org/10.9770/jesi.2019.7.1(23)

on the activities of the enterprises. Thus, the timely use of anti-crisis management can help them create adequate conditions to ensure financial stability and competitiveness.

In scientific literature, anti-crisis management is determined as a use of radical measures in order to survive (Aleksandrov, 2010). Economists describe anti-crisis management as activities intended for an enterprise to overcome a condition when a threat is posed to the functioning of the enterprise, and the enterprise's survival is considered as the main objective (Grant, 2003; Korotkova, 2009; Brauer, 2013; Baikovs, Zariņš, 2013; Wahl, Prause, 2013; Jankelová et al., 2018). Such activities are characterised by an intensive and expeditious application of certain measures and methods designed to overcome the critical condition of the enterprise. In such cases, the focus is placed on the issues of the situation along with the speedy implementation of targeted measures (De Pamphilis, 2010; Sakalas, Virbickaitè, 2011).

Some authors focus exclusively on crisis diagnostics and bankruptcy proceedings, completely forgetting about methods of anti-crisis management. Others argue that for anti-crisis management, it is essential to ensure such conditions that financial difficulties could not be of a permanent and stable nature (Goodhart, 2006; Baldin et al., 2011; Bragg, 2012; Brauer, 2013; Baikovs, Zariņš, 2013; Laužikas, Krasauskas, 2013).

Anti-crisis management, in its widest sense, is a system of managerial measures to diagnose, prevent, neutralize and overcome crisis phenomena and their causes at all levels of the economy. In other words, it is risk management and prevention of bankruptcy (Larionova, 2016).

Consequently, if the enterprise, at the present stage of its development, is functioning successfully, the goal of anti-crisis management is to prevent a crisis situation with preventive measures. If the enterprise is in a crisis situation, the goal of crisis management is financial improvement of the enterprise, application of measures to prevent bankruptcy, overcoming the crisis.

There are many reasons for crisis. They are divided into objective, related to the cyclical needs of modernisation and restructuring of the enterprise, as well as adverse environmental effects, and subjective, reflecting errors and voluntarism in management, as well as psychological factors. The causes for the crisis can be natural, which is associated with the phenomena of climate, earthquakes, floods and other natural disasters, and they may have an anthropogenic character associated with human activity. The causes for the crisis may be external and internal. The external ones are related to trends and strategies of macroeconomic development, or even the development of the world economy, competition, political situation in the country. The internal ones are connected with the problems that arise at the enterprise itself (Vasylenko, 2005). According to Khandiy (2012), the wrong perception of reality management and implementation of the false vision, creating the illusion of the enterprise's perfection, risky marketing strategy, internal conflicts and shortcomings in production, inadequate governance, innovation and investment policy, and sometimes inadequate actions and habits of executives belong to such problems. Therefore, the first place among the causes of internal crisis situations belongs to the influence of the human factor.

Enterprise anti-crisis management pursues the aim of timely diagnosing the threat of enterprise bankruptcy and the extent of the critical condition, developing and implementing appropriate measures intended to overcome the critical condition of the enterprise and restore its solvency and financial stability. Moreover, the enterprise, relying on the main principles of anti-crisis management, develops a specific action plan that meets the stages of enterprise anti-crisis management. Anti-crisis management is based on the relevant principles and stages which distinguish anti-crisis management from ordinary corporate governance (Garškaitè-Milvydienè, 2014).

The most common measures of crisis prevention at the enterprise comprise: strategic planning, adequate resource allocation at all levels of governance, the use of an effective system of control, involvement of external 


\section{ENTREPRENEURSHIP AND SUSTAINABILITY ISSUES}

ISSN 2345-0282 (online) http://jssidoi.org/jesi/

2019 Volume 7 Number 1 (September)

http://doi.org/10.9770/jesi.2019.7.1(23)

consultants when there is insufficient competence of management on various issues, competitiveness analysis, market analysis, financial analysis, human resource performance motivation system analysis, risk forecasting and taking measures on their reduction (Pestun et al., 2007).

Realisation of crisis management measures in practice allows enterprises to reduce the size of possible losses, to reduce the likelihood of emerging crisis situations, to increase the potential for counteraction to crisis phenomena, to improve the adaptability of enterprises and to strengthen their competitive positions in the market.

Anti-crisis management also involves objective evaluation of enterprises' development prospects for the longterm period, aimed at preserving the existing and forming new competitive advantages in order to increase the competitiveness of enterprises, as well as their profitability. Formation and development of competitive advantages can be an important component of enterprise anti-crisis management.

According to Porter (1985), "competitive advantages are a combination of factors that determine the success or failure of an enterprise in competition, productivity of resource use, etc". Lambin et al. (2007) understands competitive advantage as "a feature or quality (attribute) of the product or a trademark that provides the company with an edge over its direct competitors. This advantage is determined by comparison with the best (the most dangerous, priority) competitors". According to Azoev and Chelenkov (2000), "competitive advantages are a concentrated manifestation of advantages over competitors in economic, technical, organizational spheres of the enterprise, which can be measured by economic indicators (additional profit, higher profitability, market share, sales). Competitive advantage cannot be identified with the potential opportunities of the enterprise. Unlike opportunities, this is the fact that is fixed as a result of real and unquestionable preferences of customers".

Formation of competitive advantages occurs under the influence of two types of factors: strategic and tactical. Strategic factors arise when the enterprise outperforms its competitor by a factor in its external or internal environment over a long period of time. Tactical factors arise when the enterprise outperforms its competitor regarding certain elements of the external and internal environment in the near future.

Among scientists, there is no unambiguous idea about the definition of sources of the formation of competitive advantages. Shekhovtseva (2001) notes that factors of production (natural resources, favourable conditions for the production of goods, skilled labour); effective investment in education, technology, licenses; creation of new types of products, production processes and other innovations; use of created wealth to ensure economic growth should be considered the sources of competitive advantage. Lihonenko (2005) highlights a significant reduction in the cost of production at the expense of lower prices for the purchase of material, labour and financial resources; an increase in activity volume, consolidation of enterprises allowing minimizing management and conditional fixed expenses; deploying activities in segments with better conditions, such as the best tax climate as sources for achievement of competitive advantages. Other scientists (Campbell et al., 2003) consider the following factors to be the sources of the emergence of excellent opportunities of the enterprise: the structure - a unique network of internal and external relations of the organisation, which provides it with highly effective activities, that is, the existence of such unique relationships with suppliers, distributors and customers that competitors do not enjoy; a reputation based on several sources, including product quality, characteristics, design, service, etc.; innovations the ability of an enterprise to outpace competitors and hold leadership depending on its achievements in research, design, new developments and marketing policies; strategic assets - a natural monopoly, patents and copyrights restricting competition also contribute to the acquisition of competitive advantage. Vasylenko and Tkachenko (2004) note that the most typical sources of competitive advantage can be attributed to: new technologies; changes in the structure and value of individual elements in the technological chain of production and sales of goods; new consumer requests; emergence of a new segment of the market; changing the rules of the game on the market. Scientists provide a special source of information about their own business, as well as professional skills that enable them to receive and process such information in such a way that the result is a certain competitive 


\section{ENTREPRENEURSHIP AND SUSTAINABILITY ISSUES}

ISSN 2345-0282 (online) http://jssidoi.org/jesi/

2019 Volume 7 Number 1 (September)

http://doi.org/10.9770/jesi.2019.7.1(23)

advantage.

Summing up the approaches of different scientists to determination of the sources of competitive advantage formation, we have identified the following main sources of competitive advantage formation: the presence of qualified staff; use of innovations, modernisation of equipment, creating new products and services that meet the needs of the consumers; setting prices oriented on demand and competition; improving quality of goods and services; high level of social responsibility.

Depending on the various factors, Lambin et al. (2007) grouped the company's competitive advantages into two categories that can be internal and external. A competitive advantage is internal if it is based on the preponderance of the enterprise in terms of production costs, enterprise management or production, which creates value for the manufacturer, making it possible to achieve a lower cost than the competitor. The internal competitive advantages include: production; technological; qualificational; organizational; managerial; innovative; hereditary; economic and geographic. The analysis shows that the basis of the overall competitive advantage of the enterprise is the internal competitive advantages that reflect the potential of the enterprise to achieve its competitive position. External competitive advantages, on the one hand, orient the enterprise to develop and use those or other internal advantages, but, on the other hand, they provide it with stable competitive positions, since they are oriented towards the purposeful satisfaction of the needs of a specific group of consumers. The company is not able to influence the external factors quickly, but the internal factors are almost completely controlled by the management of the enterprise, that is, management has all the necessary conditions for controlling these factors (Lambin et al., 2007).

The purpose of the research is to substantiate the feasibility of forming and developing enterprise competitive advantages as a component of anti-crisis management.

\section{An Overview of the Current State of Information and Telecommunications Enterprises}

Information and communication technologies and information and communication systems under the current conditions of global civilization development are the key resource of society and the state, as well as a necessary precondition for their competitiveness in the global market. It is the information sphere that can act as a leading factor in the implementation of the most important social projects of dynamic development, the formation of civil society, the entry into the world community, etc. The European Digital Agenda for Europe 2020 initiative identifies the role of information and communication technologies as a key factor in building up the social and economic potential of cutting-edge technologies, an important information environment for society as a whole, enhancing the well-being of its citizens, and automating entrepreneurship (Senchenko, Hladkov, 2016).

As it is stated in the Law of Ukraine "On the Basic Principles for the Development of an Information-Oriented Society in Ukraine for 2007-2015": "One of the main priorities of Ukraine is the desire to build a people-centred, open to all and development-oriented information society in which everyone could to create and store information and knowledge, have access to them, use and exchange them, in order to enable each person to fully realize his or her potential, promoting social and personal development and promoting and quality of life" (Verkhovna Rada of Ukraine, 2007). The objectives, goals and directions of the development of the information society in Ukraine were defined together with the adoption of the Law.

Under globalization and the universal processes of informatisation in the global economy, the telecommunication market, which demonstrates stable and high growth rates, is becoming increasingly important. The rapid growth of the telecommunications market has been a result of the rapid development of science and technology, raising the standard of living of people with new needs emerging in telecommunication equipment and services, in particular, in the services of mobile communication, Internet and satellite television. 
The telecommunications sector, at the present stage, is one of the priorities in the economic development of many states, including Ukraine, for information exchange plays a decisive role in gaining competitiveness, both in the Ukrainian and world markets of goods and services. Telecommunications, as the final product of the operators' activities, have certain characteristics (Zagorulko et al., 2015):

1) telecommunication services are usually provided during the long period of time;

2) the process of providing communication services cannot be separated from their consumption;

3 ) the calculation of the cost of services is determined by taking into account many indicators, usually once a month, in the totality of services provided for this period;

4) the process of information transfer is two-way, between two subscribers located at different geographical points inside or outside the country.

Table 1. The Dynamics of the Number of the Information and Telecommunications Enterprises in Ukraine, Units

\begin{tabular}{|c|c|c|c|c|c|c|}
\hline \multirow{2}{*}{ Indicator } & \multicolumn{5}{|c|}{ Year } & \multirow{2}{*}{$\begin{array}{c}2017(\%) \\
\text { to } 2015\end{array}$} \\
\hline & 2013 & 2014 & 2015 & 2016 & 2017 & \\
\hline Large Business Entities & 12 & 6 & 6 & 6 & 6 & 50,00 \\
\hline Medium Business Entities & 406 & 374 & 338 & 331 & 324 & 79,80 \\
\hline $\begin{array}{l}\text { Small Business Entities, } \\
\text { including }\end{array}$ & 14467 & 12939 & 13273 & 11595 & 13083 & 90,43 \\
\hline Micro Business Entities & 12304 & 11113 & 11530 & 9933 & 11397 & 92,63 \\
\hline Total & 14885 & 13319 & 13617 & 11932 & 13413 & 90,11 \\
\hline
\end{tabular}

Source: authors`own calculations using the data given by the State Statistics Service of Ukraine

According to the data of Table 1, in Ukraine, during the period of 2013-2017, among the information and telecommunications enterprises, the small business entities, in particular micro business entities, accounted for the largest number, although their number declined in dynamics. The number of subjects of large and medium business entities also decreased, which accordingly led to a fall in the total number of the information and telecommunications enterprises in 2017 compared with 2013 by $9,89 \%$.

During the period analysed, there were some changes in the structure of cash inflows from the sale of goods and services by information and telecommunications enterprises (Table 2).

Table 2. The Dynamics of the Cash Receipts from Sale of Goods and Services by the Information and Telecommunications Enterprises in

\begin{tabular}{|c|c|c|c|c|c|c|c|c|c|c|c|}
\hline & & & & & Ukraine & & & & & & \\
\hline \multirow{3}{*}{ Indicator } & \multicolumn{10}{|c|}{ Year } & \multirow{3}{*}{$\begin{array}{c}2017 \\
(\%) \text { to } \\
2013\end{array}$} \\
\hline & \multicolumn{2}{|c|}{2013} & \multicolumn{2}{|c|}{2014} & \multicolumn{2}{|c|}{2015} & \multicolumn{2}{|c|}{2016} & \multicolumn{2}{|c|}{2017} & \\
\hline & $\begin{array}{c}\text { million } \\
\text { UAH }\end{array}$ & $\%$ & $\begin{array}{c}\text { million } \\
\text { UAH }\end{array}$ & $\%$ & $\begin{array}{c}\text { million } \\
\text { UAH }\end{array}$ & $\%$ & $\begin{array}{l}\text { million } \\
\text { UAH }\end{array}$ & $\%$ & $\begin{array}{c}\text { million } \\
\text { UAH }\end{array}$ & $\%$ & \\
\hline Large Enterprises & 39236,0 & 48,8 & 36411,2 & 43,3 & 38495,5 & 38,3 & 39808,6 & 33,9 & 42601,0 & 30,6 & 108,6 \\
\hline $\begin{array}{l}\text { Medium-Sized } \\
\text { Enterprises }\end{array}$ & 24181,7 & 30,1 & 28797,5 & 34,2 & 36183,3 & 36,0 & 44258,3 & 37,7 & 55554,6 & 39,9 & 229,7 \\
\hline $\begin{array}{l}\text { Small Enterprises, } \\
\text { including }\end{array}$ & 16992,7 & 21,1 & 18894,9 & 22,5 & 25911,6 & 25,7 & 33340,3 & 28,4 & 40961,4 & 29,5 & 241,1 \\
\hline Microenterprises & 6032,2 & 7,5 & 6557,2 & 7,8 & 9468,7 & 9,4 & 13452,6 & 11,5 & 17004,1 & 12,2 & 281,9 \\
\hline Total & 80410,4 & 100,0 & 84103,6 & 100,0 & 100590,4 & 100,0 & 117407,2 & 100,0 & 139117 & 100,0 & 173,0 \\
\hline
\end{tabular}

Source: authors`own calculations the data given by the State Statistics Service of Ukraine

It should be noted that in the period of 2013-2017, small business entities predominated in Ukraine, however, the cash receipts from the sale of their goods and services were the smallest. As a whole, a positive tendency to 
increase cash receipts from sales of goods and services of all sizes of information and telecommunications enterprises, namely, in general, within the period of five years by $73 \%$ can be noticed.

The study found that a decrease in the number of information and telecommunications enterprises was primarily due to the presence of a large number of enterprises in the market and a high level of competition.

As shown in Fig. 1, considering large information and telecommunication enterprises, the amount of losses from the sale of goods and services in 2014 and 2015 was slightly higher than the amount of profits, and during all other years, the profits were significantly higher than the losses. At the same time, during 2013-2015, half of large enterprises were unprofitable, and since 2016, the share of unprofitable enterprises in their total number decreased to $33.3 \%$.

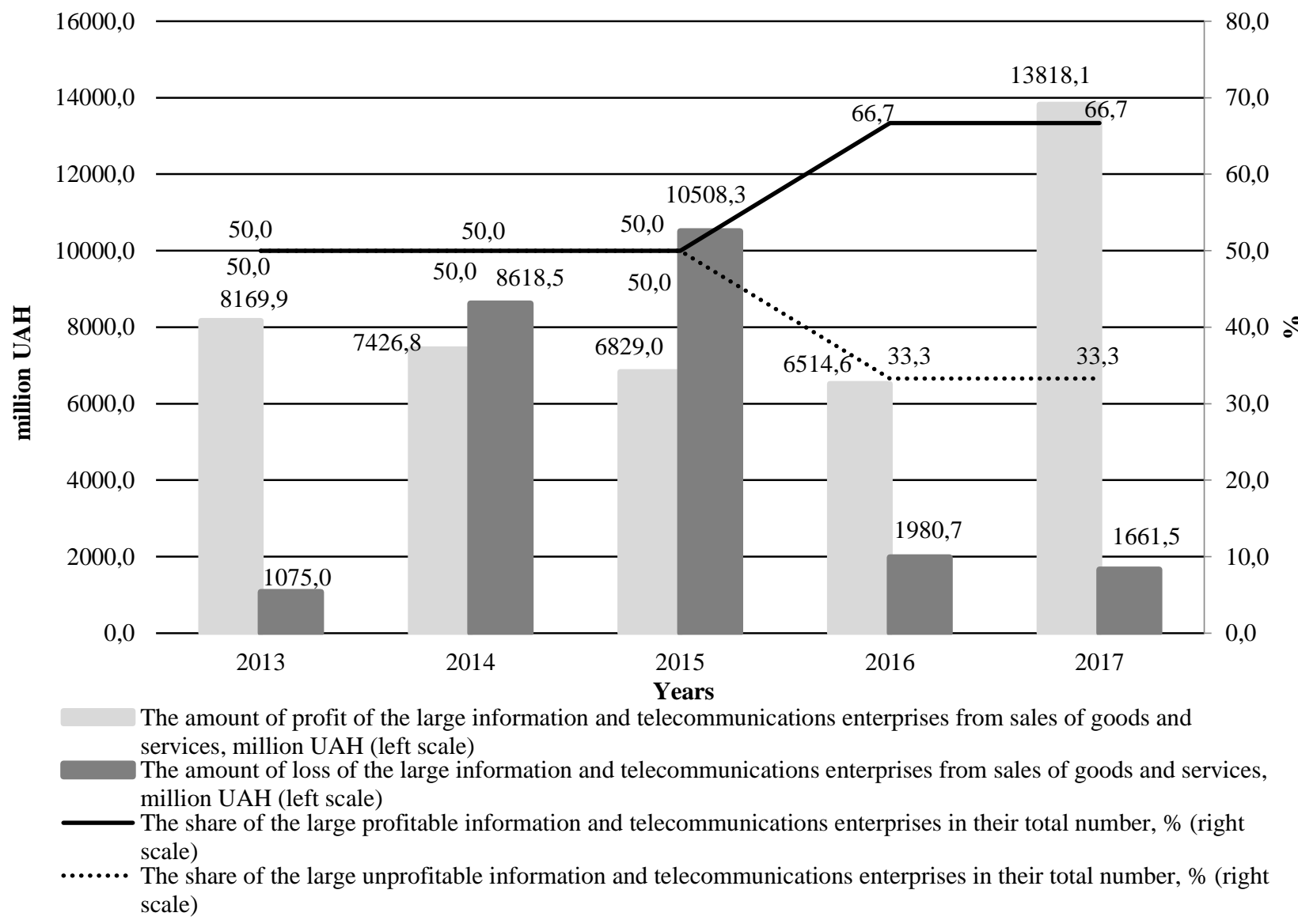

Fig. 1. The Dynamics of the Number of the Large Profitable and Unprofitable Information and Telecommunications Enterprises of Ukraine and the Amounts of Their Profit and Loss

Source: author's own calculations using the data given by the State Statistics Service of Ukraine

Since the current conditions of functioning of telecommunication enterprises are characterised by constant changes (increasing the efficiency of management of business processes, increasing the dynamics of consumer lifestyle and their demands under the influence of increasing information availability and improvement of technological and innovative components), the speed of growth in the quality of goods and services should be consistent with existing changes and timely upgrade. Therefore, the success of an enterprise depends on the 
ability to effectively use its competitive advantages, and consequently - to increase its competitiveness. That tendency has been observed in recent years in the activities of large telecommunication enterprises. In addition, owners of most of the major telecommunications companies in Ukraine are foreigners who invest a significant portion of funds in expansion and modernization of their activities, which, accordingly, enables consumers to enjoy services that meet international standards.

According to the data of Fig. 2, the amount of losses received by the medium-sized information and telecommunications enterprises in Ukraine during 2014-2016 was considerably higher than the amount of profits, which accordingly led to a decrease in their number during the period under study. However, a positive tendency, namely, the share of profitable enterprises in the total number of medium-sized telecommunication enterprises increasing annually can be observed, which indicates strengthening of the positions of that category of enterprises.

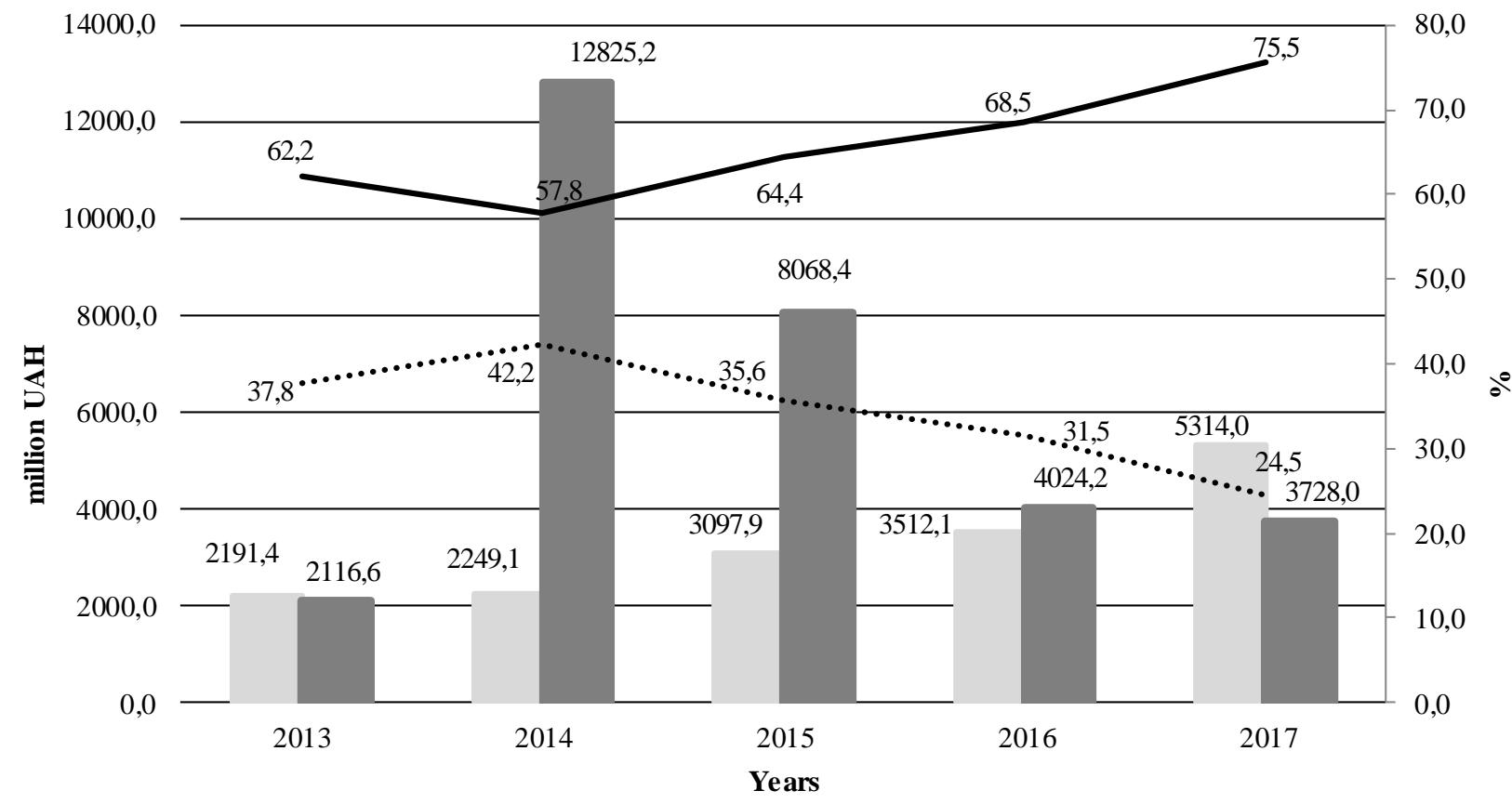

The amount of profit of the medium-sized information and telecommunications enterprises from sale of goods and services, million UAH (left scale)

The amount of loss of the medium-sized information and telecommunications enterprises from sale of goods and services, million UAH (left scale)

The share of the medium-sized profitable information and telecommunications enterprises in their total number, $\%$ (right scale)

....... The share of the medium-sized unprofitable information and telecommunications enterprises in their total number, $\%$ (right scale)

Fig.2. The Dynamics of the Number of the Medium-Sized Profitable and Unprofitable Information and Telecommunications Enterprises of Ukraine and the Amounts of Their Profit and Loss

Source: authors`own calculations using the data given by the State Statistics Service of Ukraine

A similar situation is observed with respect to the performance of the small telecommunication enterprises: in 2013-2015, the amount of losses was higher than that of profits, and only since the year 2016, there was an opposite tendency (Fig. 3). As for the share of the unprofitable enterprises in the total number of small telecommunication enterprises, it had decreased by 2015, and since 2016 it began to increase again, indicating a decrease in the competitiveness of small enterprises and their displacement from the market. 


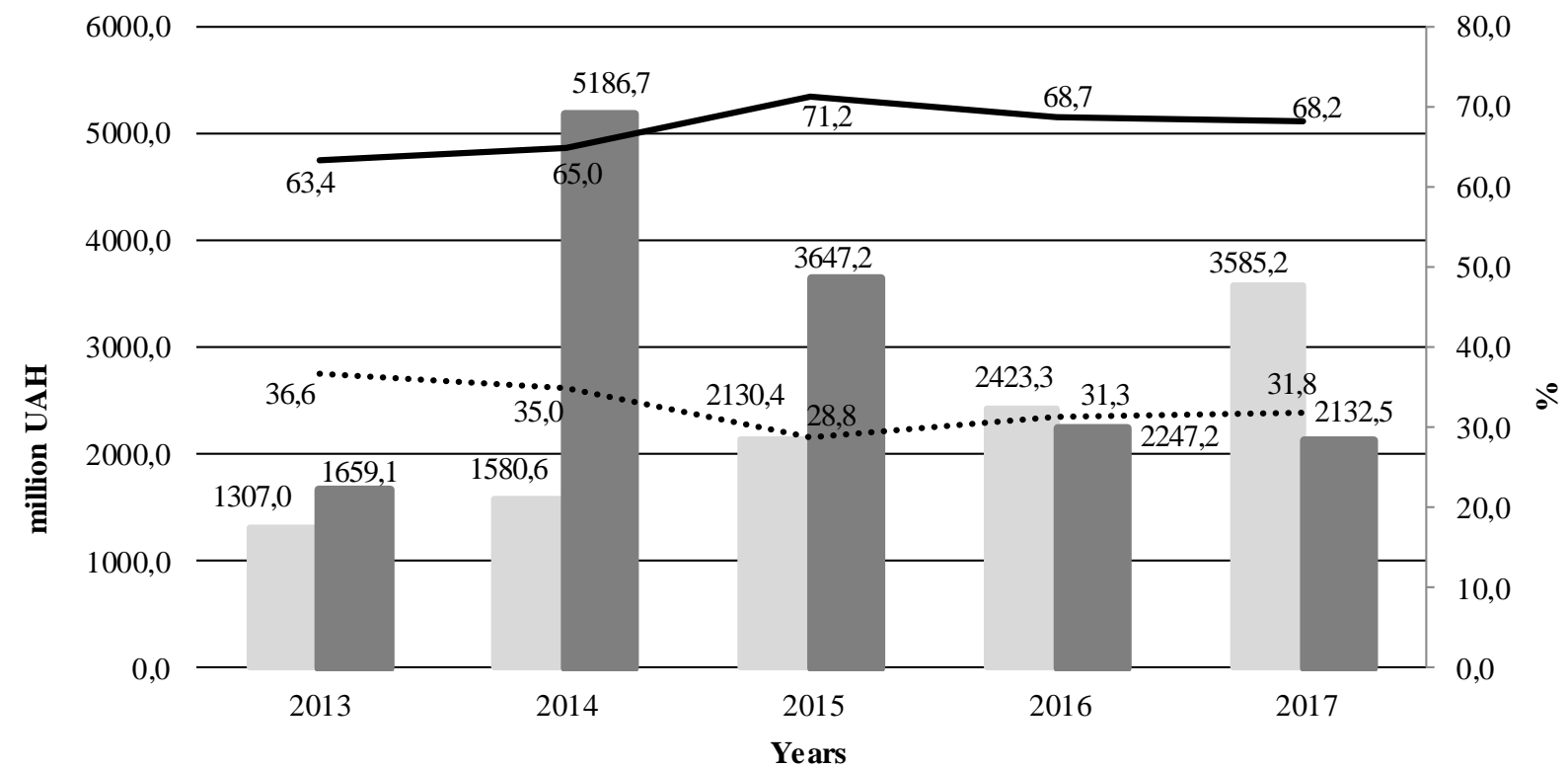

The amount of profit of the small information and telecommunications enterprises from sale of goods and services, million UAH (left scale)

The amount of loss of the small information and telecommunications enterprises from sale of goods and services, million UAH (left scale)

The share of the small profitable information and telecommunications enterprises in their total number, \% (right scale)

....... The share of the small unprofitable information and telecommunications enterprises in their total number, $\%$ (right scale)

Fig.3. The Dynamics of the Number of the Small Profitable and Unprofitable Information and Telecommunications Enterprises of Ukraine and the Amounts of Their Profit and Loss

Source: authors`own calculations using the data given by the State Statistics Service of Ukraine

Summarizing the above-mentioned, the following reasons for the slow/weak development of small and medium telecommunication enterprises can be distinguished:

- lack of appropriate economic incentives for attracting investment resources into innovative processes, in particular, availability of credit resources;

- limited amount of financing of science and innovation activities, as well as irregular and not always guaranteed stimulation of telecommunication business support and development programmes;

- lack of clear guidelines for the development of enterprises on an innovative basis;

- low qualification, quite low level of competence of employees of enterprises due to low experience in telecommunications, lack of staff skills in communication management etc.;

- excessive competition with foreign companies;

- lack of efficient and effective cooperation between large, medium and small telecommunication enterprises;

- an increase in the degree of various types of risk, in particular, the excessive risk of competition and the emergence of mass bankruptcy of enterprises;

- the presence of constant changes in the market of telecommunication services, the need for periodically appropriate updates and upgrades.

Telecommunication enterprises provide their customers with various types of services, which can be grouped as the following ones: fixed telephony services; mobile communication; broadcasting, retransmission of television and radio programmes, technical maintenance and exploitation of equipment in broadcast networks, radio communication; Internet services and other services that include telegraph and satellite communications, wireline broadcasting, etc. The share of the cash inflows from the sale of these types of services is different (Figure 4). 
Thus, more than half of the cash receipts over 2013-2017 was received from providing mobile communications services. However, the share of the cash receipts from providing mobile communications is decreasing annually, whereas the share of the cash inflows from Internet services is increasing.
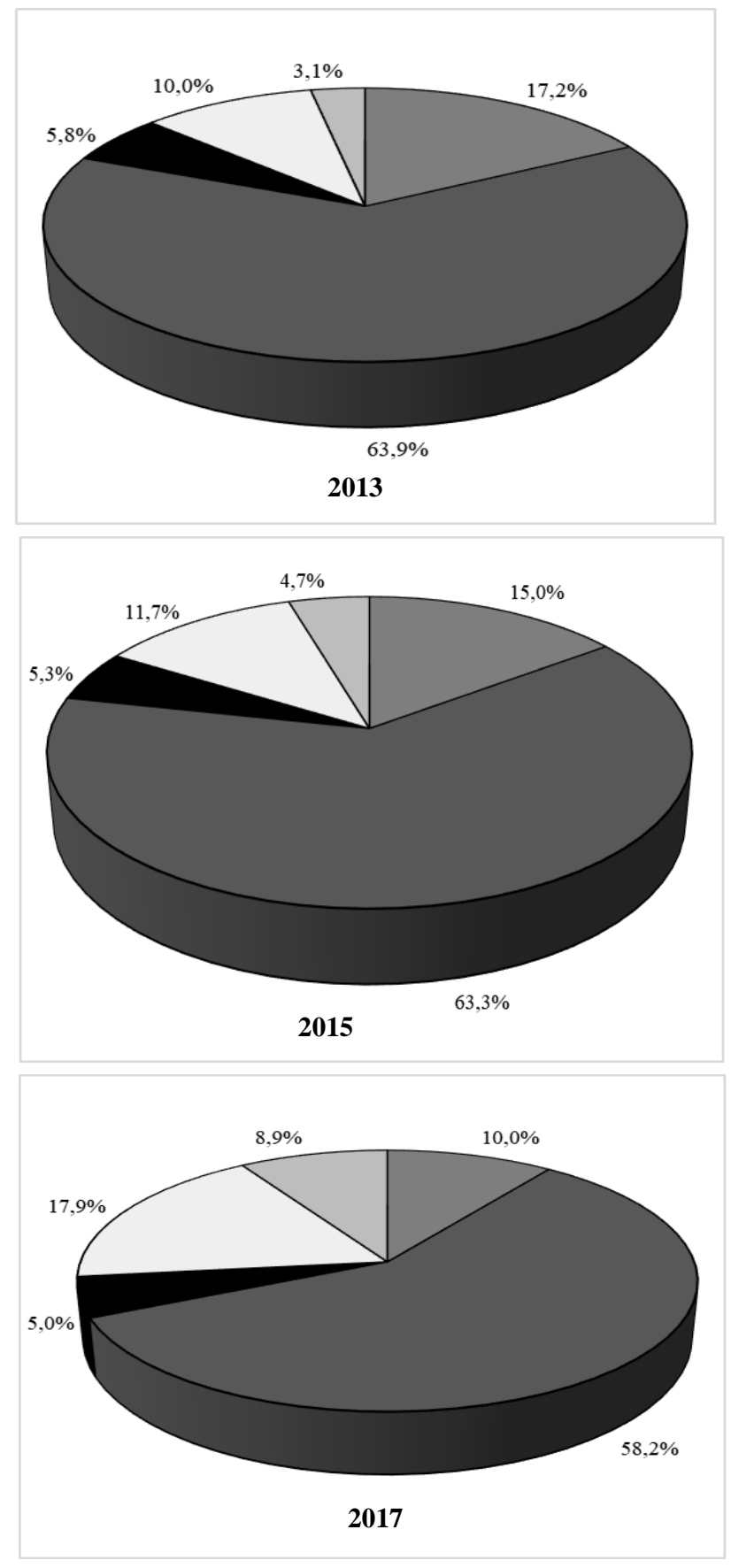
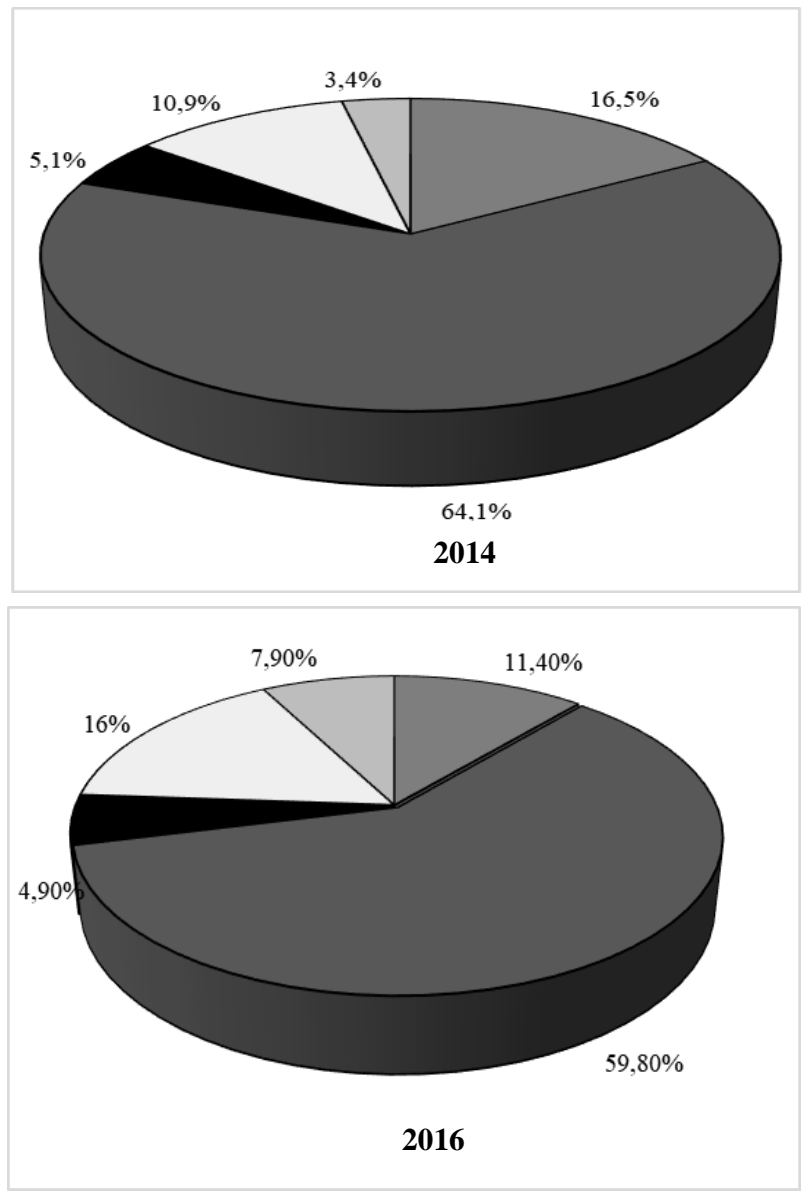

- Fixed telephony

Mobile communication

- Broadcasting, retransmission of television and radio programmes, technical maintenance and exploitation of equipment in broadcast networks, radio communication

Internet services

Other services

Fig.4. The Dynamics of the Share of Cash Receipts from Selling Goods and Services by the Information and Telecommunications Enterprises

Source: authors`own calculations using the data given by the State Statistics Service of Ukraine 
According to the results of the conducted research, the development of the telecommunication market of Ukraine began precisely from mobile communication. It originated in 1992 with the establishment of the joint UkraineDanish-German-Dutch company UMC that received a license for mobile communication and frequencies. The important date in the development of the mobile communication in Ukraine was 1 July 1993 when the company UMC launched the first mobile communication network in Ukraine of analogue NMT standard. The next step was the establishment of Kyivstar company in 1994. The first call on that operator network took place on 9 December 1997. As a result of the emergence of two mobile operators, the mobile communication market became competitive (Zagorulko et al., 2015).

Figure 5 shows the dynamics of the number of subscribers of mobile communications in Ukraine and the income from providing services to them.

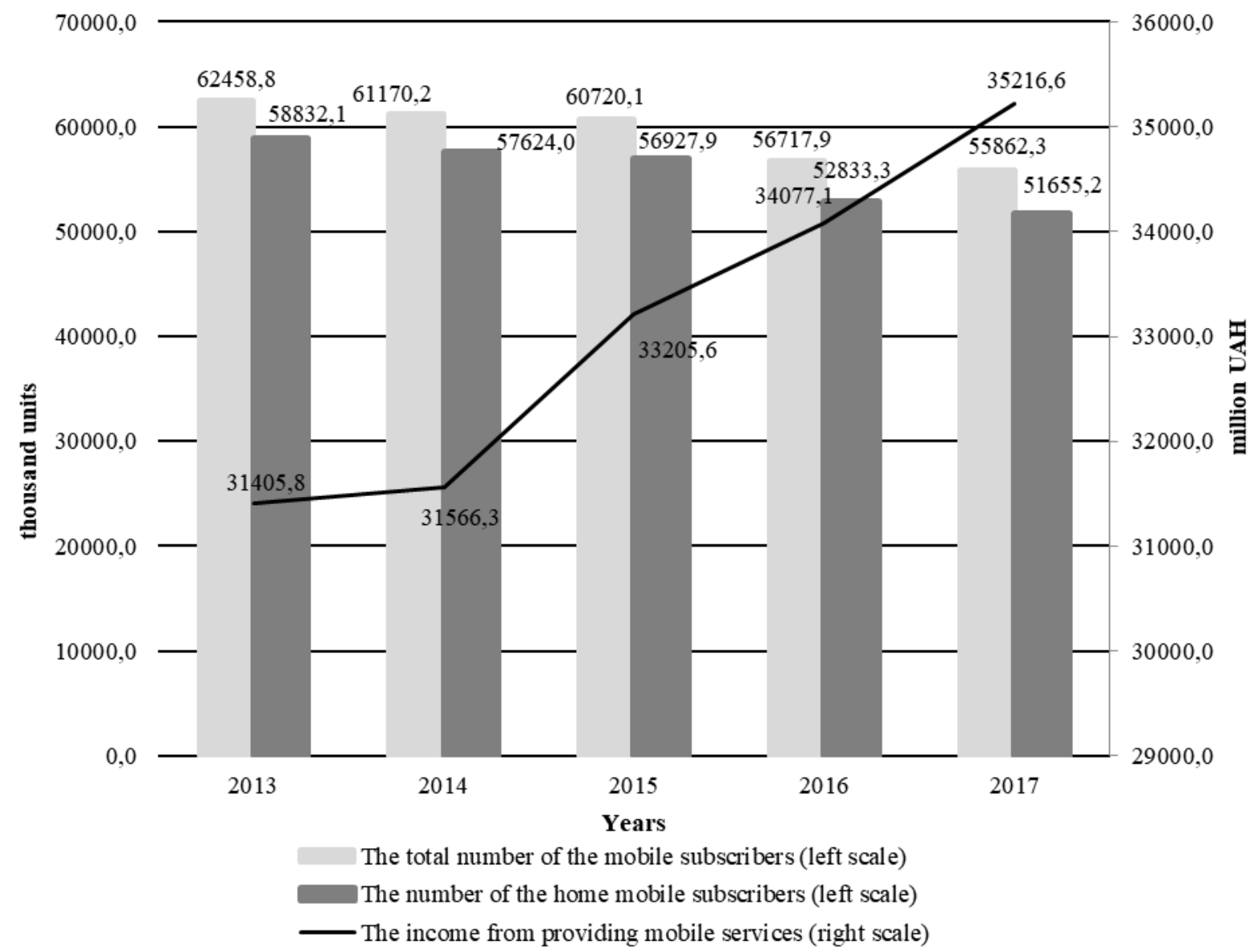

Fig.5. The Dynamics of the Number of the Mobile Communication Subscribers in Ukraine and the Income from Providing Services to Them

Source: authors`own calculations using the data given by the State Statistics Service of Ukraine

As shown in Fig. 5, during the period under study, the number of subscribers of mobile communications decreased annually, whereas the income from providing services to them increased. That can be explained by the fact that due to the annual increase in prices for package services of mobile operators, there was a decline in the simultaneous use of several SIM cards by subscribers. 


\section{ENTREPRENEURSHIP AND SUSTAINABILITY ISSUES}

ISSN 2345-0282 (online) http://jssidoi.org/jesi/

2019 Volume 7 Number 1 (September)

http://doi.org/10.9770/jesi.2019.7.1(23)

In 2018, there were 5 companies operating on the territory of Ukraine, providing mobile communication and mobile Internet services. Certain companies were the first, and they remained in the leading position, namely, PJSC Kyivstar and PJSC Vodafone Ukraine (former UMC). LLC Lifecell also occupied an outstanding place in the market, but significantly inferior to the leaders. The smallest market share was occupied by Intertelecom and TriMob LLC.

Mobile operators offer access to the UMTS-HSPA+ standard, also known as the third generation mobile communications (3G) standard. In addition to 3G, standards such as GSM (2G), CDMA2000 (3G) and LTE (4G) operate on the territory of the country. $4 \mathrm{G}$ is the most up-to-date and high-quality standard, which has increasingly been covering the territory of Ukraine recently.

Today, the mobile communications market is rapidly evolving and changing, which provides it with high attractiveness for investors. The largest region in the world with the number of mobile subscribers is North America, then - Western Europe, the countries of the Asia-Pacific region and Japan. Speaking of individual countries, the leaders in the use of mobile phones are the Scandinavian countries (Yatskevych, 2010).

As for the Ukrainian mobile communications market, there are some problems in its development, namely: technological backwardness of market players and the presence of general economic barriers to development. The dynamism of the market determines the need for operators to continuously improve existing services and implement new ones to meet the growing needs of users and maintain competitive advantage. At the same time, it is important to implement enterprise anti-crisis management.

\section{Research Methodology}

One of the objectives of enterprise anti-crisis management suggesting development of its competitive advantages is ensuring profitability. As it can be seen from practice, the profits from sale of goods and services account for the main part of the total enterprise profit. When forming that kind of profit, the final result is defined as the difference between incomes received from sale of goods and services and the costs that the enterprise carries. Therefore, in general, formation of profits from selling goods and services is managing revenue from sales and incurred costs.

To determine the key indicators of the impact of costs on the formation of profits of communications companies, multivariate correlation-regression analysis was used (Marmoza, 2013; Husarov, 2002; Mazurenko, 2006; Tarasenko, 2006; Halytska, Kovtun, 2012; Horkavyi, 2012). It has the following stages:

Stage 1. Selecting all possible factors that affect the indicator (or process) that is being studied. Each factor determines the numerical characteristics, if some factors cannot be quantified/qualitatively determined or statistics are not available, they are removed from further consideration.

Stage 2. Choosing the kind of regression or multivariate model, i.e. finding an analytic expression that reflects the connection of factor characteristics with the resultant (function selection) the fullest (Marmoza, 2013):

$$
\hat{Y}=f\left(x_{1}, x_{2}, x_{3}, \ldots, x_{d}\right),
$$

where $\hat{Y}$ - effective sign-function; $x_{1}, x_{2}, x_{3}, \ldots, x_{d}-$ a factor of the sign.

In practice, the multiple regression equations are linearised: 


$$
\hat{Y}=a_{0}+a_{1} x_{1}+a_{2} x_{2}+\ldots+a_{d} x_{d}
$$

where $a_{0}, a_{1}, \ldots, a_{d}$ - equation parameters to be determined.

If each factor, including effective first signs, is known, $d$ values $y_{h}, x_{1 h}, x_{2 h}, \ldots, x_{d h}$, when $h=1,2, \ldots, m$, then using the standard procedure of the least squares method, a system of linear algebraic equations for the estimation of the parameters of the regression equation is obtained:

$$
\left\{\begin{array}{l}
a_{0} m+a_{1} \sum_{j=1}^{m} x_{1 j}+a_{2} \sum_{j=1}^{m} x_{2 j}+\ldots+a_{d} \sum_{j=1}^{m} x_{d j}=\sum_{j=1}^{m} y_{j} \\
a_{0} \sum_{j=1}^{m} x_{1 j}+a_{1} \sum_{j=1}^{m} x_{1 j}^{2}+a_{2} \sum_{j=1}^{m} x_{1 j} x_{2 j}+\ldots+a_{d} \sum_{j=1}^{m} x_{1 j} x_{d j}=\sum_{j=1}^{m} x_{1 j} y_{j} \\
\ldots \\
a_{0} \sum_{j=1}^{m} x_{d j}+a_{1} \sum_{j=1}^{m} x_{d j} x_{1 j}+a_{2} \sum_{j=1}^{m} x_{d j} x_{2 j}+\ldots+a_{d} \sum_{j=1}^{m} x_{d j}^{2}=\sum_{j=1}^{m} x_{d j} y_{j}
\end{array}\right.
$$

The received system $d+1$ of equations $d+1$ with unknowns $a_{0}, a_{1}, \ldots, a_{d}$ can be solved by methods of linear algebra. For a large number of equations, it is most appropriate to use the Gauss method with the choice of a principal element. Since the matrix of this system of linear algebraic equations is symmetric, its solution, the only one, always exists. If the number of equations is small, the inverse matrix method to solve the problem can be successfully used.

Stage 3. Checking the adequacy of the model. Doing that requires the following calculations:

- the remnants of the model, i. e. the differences between the observed and estimated values (Marmoza, 2013):

$$
u_{h}=y_{h}-\hat{y} h=y_{h}-\left(a_{0}+a_{1} x_{1 h}+a_{2} x_{2 h}+\ldots+a_{d} x_{d h}\right), h=1,2, \ldots, m
$$

- relative error of the remnants and their average value:

$$
\delta_{h}=\frac{u_{h}}{y_{h}} \cdot 100 \%, \delta=\frac{\sum_{h=1}^{m} \delta_{h}}{m} ;
$$

- mean square error of dispersion of perturbations:

- determination coefficient:

$$
\sigma_{u}=\sqrt{\frac{\sum_{h=1}^{m} u_{h}^{2}}{m-d-1}} ;
$$

$$
\boldsymbol{R}^{2}=1-\frac{\sum_{h=1}^{m} \boldsymbol{u}_{h}^{2}}{\sum_{h=1}^{m}\left(y_{h}-\bar{y}\right)^{2}}
$$




$$
R^{2}=1-\frac{\sum_{h=1}^{m}\left(y_{h}-\hat{y}\right)^{2}}{\sum_{h=1}^{m}\left(y_{h}-\bar{y}\right)^{2}} ;
$$

- coefficient of multiple correlation $R$ that is the main indicator of the density of the correlation connection of the generalized indicator with the factors:

$$
R=\sqrt{1-\frac{\sum_{h=1}^{m}\left(y_{h}-\hat{y}_{h}\right)^{2}}{\sum_{h=1}^{m}\left(y_{h}-\bar{y}\right)^{2}}} .
$$

All values are the correlation coefficient $\mathrm{R}$ interval from -1 to 1 . The coefficient sign shows the "direction" of communication: the positive value indicates a "direct" communication, negative - the "reverse" relationship, and "0" - the lack of linear correlation. If $R=\mathbf{1}$ or $\boldsymbol{R}=\mathbf{- 1}$, there is a functional connection between the signs. Multiple correlation coefficient $R$ is the main characteristic of the closeness of the relationship between effective and feature set of the signs of factors.

Stage 4. Checking the statistical significance of the results. The check is done using the Fisher's statistics with $d$ and $(m-d-1)$ degrees of freedom (Marmoza, 2013):

$$
\begin{array}{r}
F=\frac{\frac{\sum_{h=1}^{m}\left(\hat{y}_{h}-\bar{y}\right)^{2}}{d}}{\frac{\sum_{h=1}^{m}\left(y_{h}-\hat{y}_{h}\right)^{2}}{m-d-1}} \\
\text { or } \\
F=\frac{R^{2}}{1-R^{2}} \cdot \frac{m-d-1}{d},
\end{array}
$$

where $d$-the number of factors included in the model;; $m$ - total number of observations; $\hat{y}_{h}-$ estimated value of the dependent variable at h- observation; $\bar{y}$ - the average value of the dependent variable; $y_{h}-$ the value of the dependent variable in the h- observation; $R$-coefficient of multiple correlation.

According to the Fisher's table, the critical value of $F_{\kappa p} 3 d$ and $(m-d-1)$ degrees of freedom is found. If $F>F_{k p}$, it indicates the adequacy of the constructed model. If the model is not adequate, it is necessary to return to the stage of construction of the model and possibly introduce additional factors or go to the nonlinear model.

Stage 5. Checking the significance of the coefficients of the regression equation. The checking is done with help of t-statistics, which, for the parameters of a multiple regression, is (Marmoza, 2013): 


$$
t_{h}=\frac{a_{h}}{\sigma_{a_{h}}^{2}}
$$

where $\sigma_{a_{h}}$ - the mean square deviation of the estimation of the $\mathrm{h}$ parameter.

If the value $t_{h}$ exceeds the critical value, i. e. it is behind the tables of the t-criterion of Student, the corresponding parameter is statistically significant and has a significant impact on the generalizing indicator.

Stage 6. Calculating the elasticity factor. Differences in units of measurement of factors are eliminated by using partial elasticity factors given by the ratio:

$$
\varepsilon_{h}=\frac{\partial \hat{y}}{\partial x_{h}} \cdot \frac{\bar{x}_{h}}{\bar{y}}
$$

where $x_{h}-$ the average value of the $h$-parameter; $\bar{y}$-average value of the result sign.

Partial coefficient of elasticity $\varepsilon_{h}$ indicates how much percentage of the average change of the resultant variable with a change of $1 \%$ of the factor $x_{h}$ with a fixed value of other parameters.

Stage 7. Determining confidence intervals for regression parameters. Trust interval at level of reliability (1-a) is an interval with randomly defined limits with confidence level (1-a) that covers the true value of the coefficient of the regression equation $a_{h}$ and is given by dependencies $(1 \alpha)(1 \alpha)$ (Marmoza, 2013):

$$
\left(a_{h}-t_{\mathrm{\alpha} / 2, z} \sigma_{a h}^{2} ; a_{h}+t_{\mathrm{\alpha} / 2, z} \sigma_{a h}^{2}\right),
$$

where $t_{\mathrm{a} / 2, z}$ - the Student statistics with $z=m-d-1$ degrees of freedom and levels of significance $\mathrm{a} ; \sigma_{a h}^{2}-$ quantum deviation of parameter estimation $a_{h}$.

If there are $s$ random variables $x_{1}, x_{2}, \ldots, x_{r}, \ldots, x_{s}$ (the parameters being studied) represented by samples $v$ values $x_{r}=\left\{x_{r 1}, x_{r 2}, \ldots, x_{r z}, \ldots, x_{r v}\right\}$. For each pair of random variables $x_{r}$ and $x_{w}$ the equation can be used to estimate the value of the empirical linear correlation coefficient $r_{r w}$. The obtained values of the coefficients are written in the matrix in size $s \times s$ :

$$
\left(\begin{array}{cccccc}
1 & r_{12} & \ldots & r_{1 w} & \ldots & r_{1 s} \\
r_{21} & 1 & \ldots & r_{2 w} & \ldots & r_{2 s} \\
\ldots & \ldots & \ldots & \ldots & \ldots & \ldots \\
r_{r 1} & r_{r 2} & \ldots & 1 & \ldots & r_{r s} \\
\ldots & \ldots & \ldots & \ldots & \ldots & \ldots \\
r_{s 1} & r_{s 2} & \ldots & r_{s w} & \ldots & 1
\end{array}\right) .
$$

All values of the correlation coefficient $r$ belong to the interval from -1 to 1 . The sign of the coefficient shows the "direction" of the connection: the positive value indicates the "direct" connection, the negative value - the "reverse" connection, and the value " 0 " - the absence linear correlation communication. If $r=1$ or $r=-1$, there is a functional connection between the signs. The multiple coefficient of correlation is the main characteristic of the tightness of the relationship between the result sign $P I_{1}$ and a combination of factor signs $P I_{2}, P I_{3}, \ldots, P I_{p}$. When assessing the strength of the connection, the Schedule of Chaddock is used. 


\section{Research Findings}

Using a multivariate correlation-regression analysis, a model of net profit dependence from the main types of cost was constructed. The output data for calculating the model for PJSC Kyivstar are shown in Table 3.

To evaluate strength impact factors on the net profit presented in Table 3, a linear dependence model was formed:

$$
\mathrm{y}=6,15 \mathrm{x}_{1}+27,00 \mathrm{x}_{2}-2,49 \mathrm{x}_{3}-0,30 \mathrm{x}_{4}+0,32 \mathrm{x}_{5}
$$

where $\mathrm{y}-$ net profit, thousand UAH;

$\mathrm{x}_{1}$ - labour costs, thousand UAH;

$\mathrm{x}_{2}-$ costs for social events, thousand $\mathrm{UAH}$;

$\mathrm{x}_{3}$ - material costs, thousand UAH;

$\mathrm{x}_{4}$ - depreciation costs, thousand $\mathrm{UAH}$;

$\mathrm{x}_{5}$ - other operating costs, thousand $\mathrm{UAH}$.

As it can be seen from the formula (14), with the increase in labour costs and costs for social events by UAH 1 thousand, the net profit will increase accordingly by UAH 6.15 thousand and UAH 27 thousand. The human resources are explained to be the main source from which PJSC Kyivstar can increase its profits.

Table 3. The Dependence of the Net Profit on the Main Types of Expenses at PJSC Kyivstar

\begin{tabular}{|c|c|c|c|c|c|c|}
\hline Year & Net Profit & Labour Costs & $\begin{array}{c}\text { Costs for Social } \\
\text { Events }\end{array}$ & Material Costs & $\begin{array}{c}\text { Depreciation } \\
\text { Costs }\end{array}$ & $\begin{array}{c}\text { Other Operating } \\
\text { Expenses }\end{array}$ \\
\hline 2007 & 3521899 & 538038 & 105962 & 1820424 & 1224125 & 2034040 \\
\hline 2008 & 5073453 & 653172 & 133782 & 2142745 & 1316301 & 2267021 \\
\hline 2009 & 3685397 & 777758 & 157491 & 2091274 & 1453513 & 2136650 \\
\hline 2010 & 3677880 & 700433 & 165810 & 1939528 & 1350217 & 2078358 \\
\hline 2011 & 3825346 & 758346 & 176289 & 2569131 & 1369142 & 2154648 \\
\hline 2012 & 4316355 & 777189 & 196349 & 2663526 & 1399067 & 2797266 \\
\hline 2013 & 3843039 & 707965 & 198650 & 2735931 & 1517305 & 3102557 \\
\hline 2014 & 2168375 & 800403 & 214576 & 3706888 & 1709145 & 3518914 \\
\hline 2015 & 2572679 & 840032 & 208300 & 3347186 & 1797057 & 4301381 \\
\hline 2016 & 3387067 & 841395 & 126932 & 2275894 & 3671345 & 4746638 \\
\hline 2017 & 6168938 & 990737 & 152485 & 2139190 & 2255480 & 5363954 \\
\hline $\begin{array}{r}\text { The Regression } \\
\text { Coefficient of the Net }\end{array}$ & 6,15 & 27,00 & $-2,49$ & $-0,30$ & 0,32 \\
\hline
\end{tabular}

With an increase in material costs and depreciation costs by UAH 1 thousand, the net profit decreases by respectively UAH 2.49 thousand and UAH 0.30 thousand, which shows that the enterprise has necessary and sufficient number of machinery and equipment to meet customer needs. When investing in new facilities - an enterprise will not get the desired economic result.

The value of the multiplier correlation coefficient for this model is 0.99 , which suggests that there is a very strong connection between the factor and the result signs. According to the Fisher's criterion, the model is also 
statistically significant, since its calculated value of 66.75 is significantly higher than the table one under the level of significance Alpha $=0.05$ and the number of degrees of freedom 6 and $4-6.16$.

A similar situation is observed considering PJSC Vodafon. The output data for calculating the dependence of the net profit on the main types of expenses for the elements is shown in Table 4.

In order to assess the influence of factors on the net profit shown in Table. 4, a linear dependence model was formed:

$$
y=3,37 x_{1}+25,45 x_{2}-0,43 x_{3}-0,25 x_{4}-0,36 x_{5},
$$

where $\mathrm{y}-$ net profit, thousand UAH;

$\mathrm{x} 1$ - labour costs, thousand UAH;

$\mathrm{x} 2$ - costs for social events, thousand UAH;

$\mathrm{x} 3$ - material costs, thousand UAH;

$\mathrm{x} 4$ - depreciation costs, thousand UAH;

$\mathrm{x} 5$ - other operating costs, thousand UAH.

Table 4. The Dependence of the Net Profit on the Main Types of Expenses at PJSC Vodafone Ukraine

\begin{tabular}{|c|c|c|c|c|c|c|}
\hline & & & & & \\
ear & Net Profit & Labour Costs & $\begin{array}{c}\text { Costs for } \\
\text { Social Events }\end{array}$ & Material Costs & $\begin{array}{c}\text { Depreciation } \\
\text { Costs } \\
\text { Operating } \\
\text { Expenses }\end{array}$ \\
\hline 2007 & 1724578 & 238420 & 64581 & 2332450 & 1393988 & 1516936 \\
\hline 2008 & 1514108 & 273595 & 74988 & 2742772 & 1983677 & 1865004 \\
\hline 2009 & 1342256 & 291548 & 85761 & 2578146 & 2293012 & 1532450 \\
\hline 2010 & 1178119 & 312461 & 98117 & 2798431 & 2546378 & 1498730 \\
\hline 2011 & 1052825 & 347291 & 112891 & 2802558 & 2864017 & 1456344 \\
\hline 2012 & 2268388 & 419480 & 104397 & 2772332 & 2174890 & 1408661 \\
\hline 2013 & 2708271 & 453313 & 134780 & 2830760 & 1974176 & 1447801 \\
\hline 2014 & 2578371 & 502569 & 148303 & 3227404 & 1917457 & 3501335 \\
\hline 2015 & 2422663 & 542689 & 165272 & 3547174 & 1791681 & 3914072 \\
\hline 2016 & 1287803 & 619726 & 113044 & 4537584 & 2379718 & 2740672 \\
\hline 2017 & 2206463 & 682692 & 125879 & 3847369 & 2755761 & 2377369 \\
\hline The Regression Coefficient of & 3,37 & 25,45 & $-0,43$ & $-0,25$ & $-0,36$ \\
\hline
\end{tabular}

Source: authors' own calculations using the data given by PJSC Vodafone Ukraine

As can be seen from formula (15), the same as with PJSC "Kyivstar", considering PJSC Vodafon, the net profit will increase with the increase of labour costs and those for social events, and it will decrease with the increase in material costs, depreciation and other operating costs. It proves the fact that at the expense of the human resources, telecommunication enterprises have a possibility to significantly increase their profits. Therefore, it is advisable for their management to apply various measures to encourage their employees in order to obtain the desired performance. 


\section{ENTREPRENEURSHIP AND SUSTAINABILITY ISSUES}

ISSN 2345-0282 (online) http://jssidoi.org/jesi/ 2019 Volume 7 Number 1 (September) http://doi.org/10.9770/jesi.2019.7.1(23)

The coefficient of multiple correlation for the model is 0.98 , which suggests the presence of a very strong link between the factor and efficient features. According the Fisher's criterion, the model is also statistically significant, since its calculated value of 35.04 is considerably higher than the table one under the significance level of Alpha $=0.05$ and the number of degrees of freedom 6 and $4-6.16$.

Thus, with the help and above-mentioned linear models, telecommunication enterprises will be able to predict the change in the net profit by increasing or reducing their costs on labour and social events, changing their material costs, depreciation and other operating costs in order to, on the one hand, provide businesses with a stable yield, and on the other hand, to develop a mechanism for telecommunication enterprise crisis management, which provides for the timely determination of the availability and expediency of the development of competitive advantages.

The study found that the mobile communication market has very big prospects. It has been actively developing, giving a possibility to make a process of communication with other people the most comfortable, the quickest and the easiest, with each passing year communication becoming more and more accessible with its benefits being enjoyed by more and more people. However, the development of telecommunications services depends, to a large extent, on attracting investment. Moreover, diversification of communication services by making radical changes in existing package tariffs, roaming, providing Internet services, using innovative, progressive, and foreign approaches to effective management of telecommunications enterprises in a context of fierce competition are one of the most promising directions for further Ukraine's telecommunication sector development.

As Chesbrough notes (Chesbrough, 2003), today innovation is increasingly complex, fast, interactive, and requires the connection of external and internal knowledge bases. Therefore, telecommunication enterprises under dynamic market environment should implement enterprise anti-crisis management, which involves the obligatory introduction of innovations in order to obtain effective results of their activities and development of their competitive advantages.

As a result of our research, we recommend a mechanism for anti-crisis management of a telecommunication enterprise, which involves timely identification of the availability and feasibility of developing a competitive advantage of the enterprise (Fig. 6).

Implementation of the mechanism of anti-crisis management of a telecommunication enterprise is provided with the use of appropriate material, financial, human resource and intellectual resources that can be concentrated both at the level of the enterprise itself and attracted from the outside. With the help of the developed mechanism of anti-crisis management, telecommunication enterprises will be able to effectively develop and realise their competitive advantages through the coordination of all the interconnected factors that affect the formation of their profitability.

\section{Conclusions}

To draw a conclusion, anti-crisis management is a management aimed at preventing and eliminating negative business outcomes related to internal and external factors. During its activities, the enterprise should regularly conduct anti-crisis management, an important component of which, as it is evidenced by the research findings, is formation and development of competitive advantages. Competitive advantages are a set of innovative, technological, economic, environmental, consumer and managerial factors, through which the enterprise, during production and sale of goods and services, enjoys benefits compared to competitors. 


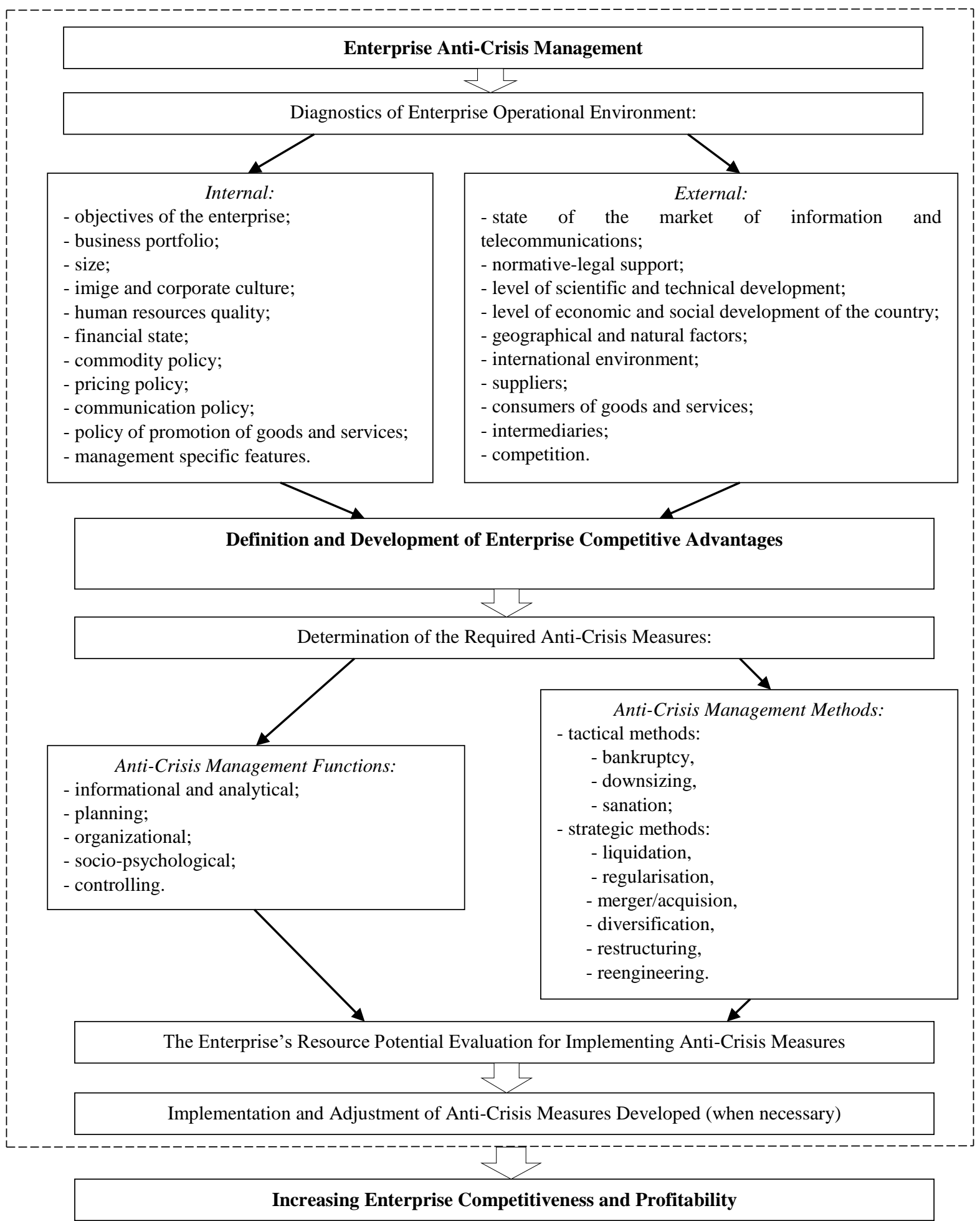

Fig.6. The Mechanism of Anti-Crisis Management of a Telecommunication Enterprise (Including the Development of Its Competitive Advantages)

Source: author's own development 


\section{ENTREPRENEURSHIP AND SUSTAINABILITY ISSUES}

ISSN 2345-0282 (online) http://jssidoi.org/jesi/ 2019 Volume 7 Number 1 (September) http://doi.org/10.9770/jesi.2019.7.1(23)

The study shows that, today, one of the priority sectors of the Ukrainian economy is the sector of information and telecommunications, from which the amount of cash receipts is annually increasing, in particular, during 2013-2017 - by 73\%. However, there is a tendency towards a decrease in the number of information and telecommunications enterprises due to the presence of a large number of enterprises in the market and a high level of competitiveness. Among the services provided by telecommunication enterprises, the most widespread are mobile connection and mobile internet services. PJSC Kyivstar and PJSC Vodafone Ukraine are the leaders in providing such services on the Ukrainian market. However, the dynamism of the market is determined by the requirement for operators to continuously improve existing services and implement new ones to effectively meet the needs of users and maintain their competitive advantage. That allows characterising the mobile communication industry as rather variable, therefore, the need for enterprises to constantly implement anti-crisis management is appropriate.

With the help of the constructed model of the dependence of net profit on the main types of expenses, telecommunication enterprises will be able to predict the change in the value of their net profit, to influence its level, regulating the value of a factor that will promote the development of competitive advantages of the enterprise. The proposed mechanism of anti-crisis management of a telecommunication enterprise is characterised by being easy to use, with access to available information for anti-crisis measures and the ability to determine the availability and feasibility of developing a competitive advantage of an enterprise. Thus, the recommendations, following from the research, allows enterprises to ensure their competitiveness and identify ways to increase their profitability.

\section{References}

Aleksandrov, G.A. 2010. Crisis Management: theory, practice, infrastructure. Moscow. 544 p. (in Russian)

Azoev, H. L.; Chelenkov, A. P. 2000. Competitive Advantage of a Firm. Moscow. 255 p. (in Russian)

Baikovs, A.; Zariņš, I. 2013. Philosophical, legal and general issues of legal liability, Entrepreneurship and Sustainability Issues 1(1): 2336. Retrieved from: http://dx.doi.org/10.9770/jesi.2013.1.1(3)

Baikovs, A.; Zariņš, I. 2013. Philosophical, legal and general issues of legal liability, Entrepreneurship and Sustainability Issues 1(1): 2336. Retrieved from: http://dx.doi.org/10.9770/jesi.2013.1.1(3)

Baldin, K.V.; Bystrov, O.F.; Rukosuev, A.V. 2011. Crisis Management: macro-and micro-level. Moscow. 316 p. (in Russian)

Bragg, S. M. 2012. Financial Analysis: a controller's guide. Wiley. 416 p.

Brauer, M. F. 2013. The effects of short-term and long-term oriented managerial behaviour on medium-term financial performance: longitudinal evidence from Europe, Journal of Business Economics and Management 14(2): 386-402. Retrieved from: https://doi.org/10.3846/16111699.2012.703965

Campbell, D.; Stonehouse, G.; Houston, B. 2003. Business Strategy: an Introduction. Butterworth Heinemann. 478 p.

Chesbrough, H. 2003. Open Innovation: The New Imperative for Creating and Profiting from Technology. Boston: Harvard Business School Press. 227 p. Retrieved from: https://www.nmit.edu.my/wp-content/uploads/2017/10/Open-Innovation-the-New-Imperative-forCreating-and-Profiting-from-Technology.pdf

De Pamphilis, D. M. 2010. Mergers, Acquisitions, and Other Restructuring Activities: An integrated approach to process, tools, cases, and solutions. Burlington: Academic Press. 751 p. Retrieved from: https://books.google.com.ua/books?hl=en\&lr=\&id=DRtQaFrC4q4C\&oi=fnd\&pg=PP1\&ots=5eHFuO25af\&sig=IC8buQpH_3gzO87hd4YLupgJY\&redir_esc=y\#v=onepage\&q\&f=false 


\section{ENTREPRENEURSHIP AND SUSTAINABILITY ISSUES}

ISSN 2345-0282 (online) http://jssidoi.org/jesi/ 2019 Volume 7 Number 1 (September) http://doi.org/10.9770/jesi.2019.7.1(23)

Garškaitè-Milvydienė, K. 2014. Anti-crisis management of enterprises and possibilities of overcoming their critical condition, Entrepreneurship and Sustainability Issues 1(4): 187-203. Retrieved from: http://dx.doi.org/10.9770/jesi.2014.1.4(1)

Goodhart, C. A. E. 2006. A framework for assessing financial stability? Journal of Banking \& Finance 30(12): 3415-3422. Retrieved from: http://www.sciencedirect.com/science/article/pii/S0378-4266(06)00126-9

Grant, W. N. 2003. Corporate Bankruptcy. Tools, Strategies and Alternatives. John Wiley \& Sons, Inc., Hoboken, New Jersey. 280 p.

Halytska, E.V.; Kovtun, N.V. 2012. Financial Statistics: a reference book. Kyiv. 440 p. (in Ukrainian)

Horkavyi, V. K. 2012. Statistics: a reference book. Kyiv. 608 p. (in Ukrainian)

Husarov, V.M. 2002. Statistics: a reference book. Moscow. 463 p. (in Russian)

Jankelová, N.; Jankurová, A.; Beňová, M.; Skorková Z. 2018. Security of the business organizations as a result of the economic crisis, Entrepreneurship and Sustainability Issues 5(3): 659-671. http://doi.org/10.9770/jesi.2018.5.3(18)

Khandiy, O.O. 2012. Anti-crisis instruments of enterprise management: practical aspects of realization. Marketing and Management of Innovations 4: 186-192. Retrieved from: http://mmi.fem.sumdu.edu.ua/sites/default/files/mmi2012 4 186 192.pdf (in Ukrainian)

Korotkova, E. M. 2009. Crisis Management. Moscow. 620 p. (in Russian)

Lambin, J.-J.; Chumpitaz, R.; Schuiling, I. 2007. Market-Driven Management: Strategic and Operational Marketing. 2nd Edition.

Basingstoke; New York: Palgrave Macmillan. 516 p. Retrieved from:

https://books.google.be/books?hl=en\&lr=\&id=c5ccBQAAQBAJ\&oi=fnd\&pg=PP1\&ots=8_173Rx5Bc\&sig=-

IPDIAsn6gw 5Ws9sZWUbQBaKhU\#v=onepage\&q\&f=false

Larionova, I.K. 2016. Anti-Crisis Management. Kyiv. 362 p. (in Ukrainian)

Laužikas, M.; Krasauskas, A. 2013. Impacts of sustainable structural growth on the economic performance of listed companies, Entrepreneurship and Sustainability Issues 1(2): 81-91. Retrieved from: http://dx.doi.org/10.9770/jesi.2013.1.2(2)

Lihonenko L.O., 2005. Enterprise under globalization: awareness of new realities. Problems and prospects of entrepreneurship development in Ukraine: collection of scientific papers. Kyiv: Kyiv National University of Trade and Economics, 310. (in Ukrainian)

Marmoza, A.T. 2013. Theory of Statistics: a manual. Kyiv. 592 p. (in Ukrainian)

Mazurenko, V.P. 2006. Theory of Statistics: a reference book. Kyiv. 232 p. (in Ukrainian)

Pestun, I. V.; Mnushko, Z. M.; Presniakova, V. V. 2007. Marketing informational support of the process of making management decisions in pharmacy, Farmatsevtychnyi zhurnal 1: 9-14. (in Ukrainian)

Porter, M. E. 1985. The Competitive Advantage: Creating and Sustaining Superior Performance. New York: Free Press. 557 p.

Private Joint Stock Company Kyivstar. Financial and analytic information. Retrieved from: https://kyivstar.ua/uk/mm.

Private Joint Stock Company Vodafone Ukraine. Financial results. Retrieved from: https://www.vodafone.ua/uk.

Sakalas, A.; Virbickaite, R. 2011. Construct of the Model of Crisis Situation Diagnosis in a Company, Inzinerine Ekonomika-Engineering Economics 22(3): 255-261. Retrieved from: http://www.inzeko.ktu.lt/index.php/EE/article/download/11751/6416

Senchenko, V. V.; Hladkov, O. V. 2016. Monitoring the development of the information society in Ukraine, Science and Science of Science 1: 16-27. Retrieved from: http://dspace.nbuv.gov.ua/bitstream/handle/123456789/132217/02-Senchenko.pdf?sequence=1 (in Ukrainian)

Shekhovtseva, L.S. 2001. Competitiveness of the region: factors and method of creation, Marketing in Russia and abroad 4(24): 11-16. Retrieved from: https://www.cfin.ru/press/marketing/2001-4/03.shtml

State Statistics Service of Ukraine, 2018. Activity of large, medium, small and micro-enterepreneurship entities. Statistical publication. Kyiv: State Statistics Service of Ukraine. Retrieved from: http://www.ukrstat.gov.ua/druk/publicat/kat_u/2018/zb/11/zb_dsp_2017.pdf 


\section{ENTREPRENEURSHIP AND SUSTAINABILITY ISSUES}

ISSN 2345-0282 (online) http://jssidoi.org/jesi/ 2019 Volume 7 Number 1 (September) http://doi.org/10.9770/jesi.2019.7.1(23)

State Statistics Service of Ukraine, 2018. Retrieved from: http://www.ukrstat.gov. ua/

Tarasenko, T.O. 2006. Statistics: a reference book. Kyiv. 344 p. (in Ukrainian)

Vasylenko, V. O. 2005. Enterprise Anti-Crisis Management: a manual. Kyiv. 208 p. (in Ukrainian)

Vasylenko, V.O.; Tkachenko, T.I. 2004. Strategic Management of the Enterprise: a manual. Kyiv. 400 p. (in Ukrainian)

Verkhovna Rada of Ukraine. 2007. Law of Ukraine No 537-V: On the Basic Principles for the Development of an Information-Oriented Society in Ukraine for 2007-2015, Kyiw, Ukraine. Retrieved from: https://zakon.rada.gov.ua/laws/show/537-16

Wahl, M.; Prause, G. 2013. Toward understanding resources, competencies, and capabilities: business model generation approach, Entrepreneurship and Sustainability Issues 1(2): 67-80. Retrieved from: http://dx.doi.org/10.9770/jesi.2013.1.2(1)

Yatskevych I. V. 2010. Organizational and economic forms of interaction of small and large enterprises in the telecommunication sector: a monograph. Odesa. 216 p. Retrieved from: http://www.dut.edu.ua/uploads/1 53 47692056.pdf

Zagorulko, V.; Zubko, L.; Sapeha, Ya. 2015. Analysis of competitionin the mobile market in Ukraine, Economics. Management. Business 2 (12): 33-40. Retrieved from: http://nbuv.gov.ua/UJRN/ecmebi_2015_2_7

Tetiana BALANOVSKA is PhD in Economics, Professor, is Professor of the Department of Management named after prof. J.S. Zavadskyi, National University of Life and Environmental Sciences of Ukraine, Kyiv, Ukraine. Scientific interests: problems of theory and practice of management and marketing, topical issues of anti-crisis management of enterprises and human resource management, entrepreneurship.

ORCID ID: orcid.org/0000-0001-6814-5888

Oksana HAVRYSH is $\mathrm{PhD}$ in Economics is Associate Professor of the Department of Management, State University of Telecommunications, Ukraine. Scientific interests: theoretical and practical aspects of research of anti-crisis management problems, strategic management, formation of effective marketing strategies of enterprises and research of the market of information and telecommunications.

ORCID ID: orcid.org/0000-0002-5756-0880

Olga GOGULYA is PhD in Economics, Associate Professor, is Associate Professor of the Department of Management named after prof. J.S. Zavadskyi, National University of Life and Environmental Sciences of Ukraine, Kyiv, Ukraine. Scientific Interests: fundamental and applied research of strategic management problems, entrepreneurship, marketing support for the functioning of enterprises, social responsibility and business ethics.

ORCID ID: orcid.org/0000-0003-4602-7543

Copyright (C) 2019 by author(s) and VsI Entrepreneurship and Sustainability Center This work is licensed under the Creative Commons Attribution International License (CC BY). http://creativecommons.org/licenses/by/4.0/

CC) (i) Open Access 